\title{
Atatürk Üniversitesi Merkez Yerleşkesi açık-yeşil alan avlusu peyzaj tasarımı ve uygulama süreci
}

\author{
Hasan YILMAZ1 \\ ${ }^{1}$ Atatürk Üniv. Mimarlık ve Tasarım Fak. Peyzaj Mimarlığı Böl. Erzurum
}

Alınıs tarihi: 27 Eylül 2018, Kabul tarihi: 20 Kasım 2018

Sorumlu yazar: Hasan YILMAZ, e-posta: hyilmaz@atauni.edu.tr

$\ddot{\mathbf{O z}}$

Üniversite yerleşkeleri fiziki yapılaşması, açık-yeşil alan planlamaları ile bulundukları kentlere sosyoekonomik, kültürel yönden katkıları kadar, estetik, ekolojik, ekonomik, rekreasyonel katkılar sağlayan alanlardır. Atatürk Üniversitesi yerleşkesi kuruluşundan günümüze sürekli gelişerek, ulaşım, eğitim, konut dokusu ve açık yeşil alanları ile ülkemizin en prestijli yerleşkelerinden birisi durumuna gelmiştir. $\mathrm{Bu}$ çalışmada Atatürk üniversitesi merkez yerleșkesindeki eğitim dokusu arasında yer alan merkez açık yeşil alan avlusu için hazırlanıp uygulaması yapılan peyzaj tasarım projesi üzerinde durulmuștur. Konu peyzaj tasarım süreci kapsamında ele alınmış ve mevcut durum ortaya konmuştur.

Anahtar kelimeler: Üniversite yerleșkesi, peyzaj tasarım projesi, peyzaj tasarım ve uygulama süreci

\section{Landscape design and application process of the open green courtyard in the Ataturk University Main Campus}

\begin{abstract}
University campuses contribute to the socioeconomic and cultural aspects of their cities through their physical construction and open-green area planning as well as providing aesthetic, ecological, economic and recreational contributions as. The Ataturk University campus is continuously developing and it is one of the most prestigious campuses of Turkey with its transportation, education, residential texture and open green areas.

In this study, the Landscape Design Project prepared and applied for the center open green area among
\end{abstract}

the educational texture of the central settlement of Ataturk University was emphasized. The subject has been evaluated in the context of landscape design process and the current situation has been revealed.

Key words: University campus, landscape design project, landscape design and application process

\section{Giriș}

Dünyada insan nüfusu kent merkezlerinde yoğunluk kazanmakta ve kent insanı her geçen gün doğadan izole edilmiş bir duruma gelmektedir. Günlük yaşam çevrelerinde yeşil alanlar insanlara bir çok fiziksel ve fizyolojik yararlar sağlamaktadır (Fuller ve ark., 2007).

Üniversite yerleşkeleri bütün dünyada alan kullanımları, yapısal ve bitkisel tasarımları ile evrensel, ülkesel ve bölgesel ölçekte model oluşturma görevini üstlenmiştir. Yerleşke planlamasında yapısal plan kararları kadar, açık yeşil alan planlaması da büyük önem taşımaktadır (Yılmaz ve Irmak, 2012). Bugün ülkemizde sayıları 200'e varan üniversitelerin tercih edilmelerinde kaliteli eğitim ve öğrenim vermenin yanı sıra yerleşkelerinin fiziki donanımları da etkili olmaya başlamıştır. Öğrenciler ve akademisyenler tarafından kolay erişilebilen, güvenli, konforlu, yerleşkesinde ve yakın çevresinde değişik aktivitelere fırsat tanıyan sosyokültürel ve rekreasyonel imkanlara sahip olan üniversiteler tercih edilmede bir adım öne geçmektedir. Nitekim Dober (2000),'e göre iyi planlanmış yerleşkelerde geniş açık-yeşil alanlar ve ağaçlar yükseköğrenimin sembolüdür. Son yıllarda artan üniversite sayılarına bağlı olarak yerleşkeler fiziki yapılarını hızla tamamlamaktadır. Ülkemizde bazı yerleşkeler konunun uzmanları ile fiziki yapılaşmalara giderek, kent ve bölge ile uyumlu, 
estetik, ekolojik, ekonomik ve rekreasyonel firsatlar sunan, bir master planı dahilinde sağlıklı gelişimlerini sürdürürken, bazı yerleşkelerde kaynaklar yanlış kullanılabilmektedir. Sosyal ve görsel medyadaki hızlı gelişimler öğrencilerin mesleki eğitimlerini seçmede etkili olduğu kadar, eğitim görecekleri üniversitelerin bulunduğu kentin ve özellikle yerleşke fiziki ve sosyal dokusunun kendilerine sunacağı firsatları değerlendirerek üniversite tercihlerinde önemli bir etken olduğu görülmektedir.

Yeşil örtünün ağırlı kazandığı üniversite yerleşkeleri mekanı kullanan öğrencilere bir çok olumlu katkı sağlar (Hipp ve ark., 2016.). Özelikle ilk üniversiteye gelen öğrenciler yeni bir sosyal ve fiziki çevre ile karşı karşıya kalmakta, ailesinden ve sosyal arkadaş çevresinden ayrıldığı için yalnızlık hissine kapılmaktadır. Hajrasouliha (2017), tarafindan yapılan bir çalışmada yerleşkelerin fiziki karakteri öğrenci memnuniyetini ve akademik performansı olumlu olarak etkilediğini, yeşil bir yerleşkenin öğrencileri sosyalleşmeye teşvik ettiğini, zihinsel yorgunluğunu azalttığı tespit etmiştir. Hodson and Sander (2017),'e göre ağaç örtüsü ile okuma performansı arasında olumlu bir ilișki olduğu gözlenmiştir.

$\mathrm{Bu}$ çalışmada, Atatürk Üniversitesi merkez yerleşkesinde gerçekleştirilen peyzaj tasarım ve uygulama sürecini ortaya koymak amaçlanmıştır.

\section{Materyal ve Yöntem}

\section{Materyal}

Çalışmanın ana materyalini Atatürk Üniversitesi merkez yerleşkesi iç meydan alanı oluşturmaktadır. $\mathrm{Bu}$ alan yaklaşık 25 bin metrekare büyüklüğünde olup, eğitim dokusu içinde yer almaktadır (Şekil 1). Çok sayıda fakülte, rektörlük binası, kütüphane ve mevcut tören alanı ile doğrudan ilişkili olan tasarım alanı kısmen korunaklı bir iç bahçe veya iç avlu şeklindedir.

\section{Yöntem}

Çalışma yöntemi; sorun tanımlama, mevcut durumu ve talepleri belirlemeye yönelik veri toplama, analiz (çevre ve tasarım analizi), alternatif tasarımların değerlendirmesi, sentez (peyzaj tasarımı), uygulama ve yönetim aşamalarından oluşmaktadır. Yöntemin belirlenmesinde Özkan ve ark., (1993) ile Yılmaz ve Yılmaz (2000)'ın çalışmalarından yararlanılmıştır. Çalışmanın ilk aşamasında yerleşke planlaması ve tasarımına yönelik yapılan çalışmalar değerlendirilmiş, yurt içi ve yurt dışındaki bazı üniversite yerleşkeleri irdelenmiştir.

İkinci aşamada peyzaj tasarımı yapılacak alanın estetik ve fonksiyonel özelikleri, kullanıcı eğilimleri ve talepleri doğrultusunda, alanda tasarım ilkeleri dikkate alınarak yeni bir peyzaj tasarımının yapılmasına karar verilmiştir. $\mathrm{Bu}$ talep ilgili yönetimlere iletilerek, onay alındıktan sonra tasarım sürecine başlanılmıştır. Alanda planlanan yapısal ve bitkisel tasarımların bir programı oluşturulmuş, mevcut durum analizi yapılmıștır. Tasarımda öngörülen yapısal ve bitkisel tasarımların işlevleri, birbirileri ve çevre ile olan ilişkileri değerlendirilerek alternatif alan tasarımları (avan proje) gerçekleştirilmiştir. Alternatif tasarımlar üniversite yönetimi ve ilgili teknik elemanları ile tartışlarak, uygulanacak kesin proje belirlenmiştir. Sonuçta uygulama projesi tasarım kararları ayrıntılı olarak (görünüş, detay, kesit, sulama, aydınlatma, metraj vb.) sentezlenerek, tasarlanan projenin alana uygulaması/aplikasyonu yapılmıştır. Uygulama sonrası alanın kullanımı, kullanıcı memnuniyetleri, bakım ve yönetimi kontrol edilerek, aksayan yönlere müdahaleler yapılmıștır.

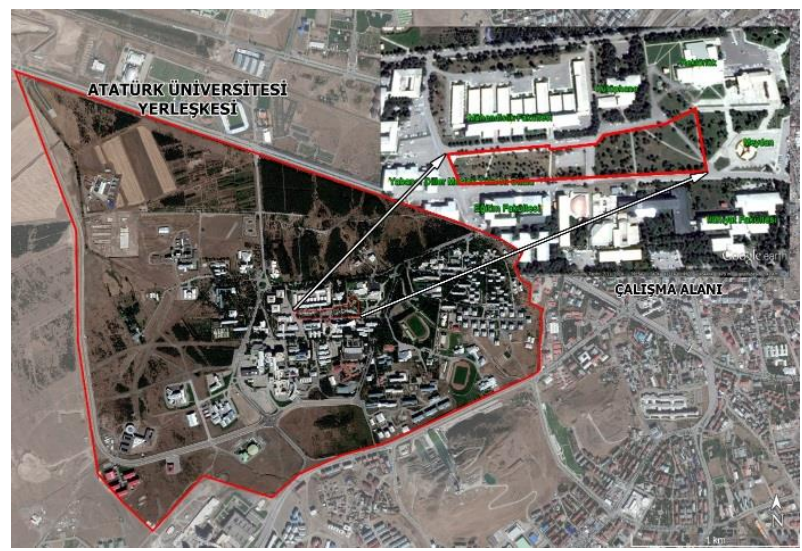

Şekil 1. Çalışma alanının konumu ve tasarım öncesi uydu görüntüsü

\section{Bulgular ve Tartışma}

\section{Peyzaj tasarım süreci}

Sürdürülebilir yerleşke planlamasında ve tasarımında birçok faktör dikkate alınmalıdır (Dober, 2000). Tasarım sürecinde; konu ile ilgili literatür çalışması, örnek yerleşkelerin yurt içi ve yurtdışında yerinde incelenmesi, alanın iklim verileri, mevcut bitkisel doku, toprak, arazi yapısı, sosyo- kültürel yapı, alan-bina, alan çevre-analizleri, kullanıcı istekleri göz önüne alınmıştır. 
Peyzaj tasarım süreci; tasarım alanın tespiti, sorun tanımlama, alanla ilgili talepler, karar vericilerin tasarım sürecine dahil edilmesi, program oluşturma, mevcut durum analizi ve alternatif avan projelerinin oluşturulması, kesin projeye karar verilmesi aşamasından oluşmaktadır. Nitekim Önder ve Polat (2001)'e göre peyzaj tasarım sürecinin göz önüne alınması peyzaj projelerinden istenilen başarının elde edilmesi için gereklidir.

Yapılan değişik bilimsel çalışmalarda öğrencilerin beklentilerinin peyzaj plan ve tasarımlarında dikkate alınması önemi vurgulanmıştır (Turgut ve ark., 2009, Öztürk ve ark., 2016, Rumao, 2016, Hajrasouliha, 2017). Peyzaj tasarım sürecinde alanın mevcut durumunun kullanıcl memnuniyeti öğrenciler ve akademik personel ile yapılan karşılıklı görüşmeler ile belirlenmiș ve alanda hangi tasarım öğelerine yer verilmesi gerektiği konusunda bilgilerine başvurulmuştur. Bu alan için peyzaj tasarım öncesi ve sonrasında başarı ölçütlerini ortaya koymak amacı ile alan kullanıc memnuniyetlerinin belirlenmesine yönelik bir yüksek lisans tezi yürütülmüştür(Aksu, 2016).

Tasarım alanı üniversite yerleşkesinin en merkezi konumunda yer almaktadır. Alan öğrenci, akademik ve idari personelin serbest zamanlarını geçirebileceği konum ve büyüklükte olup, bu fonksiyonlarını yerine getirecek alt ve üst yapı elamanlarından mahrumdur. Alan düz olup, etrafı değişik yüksekliklerde binalarla çevrelenmiş avlu şeklinde kısmen rüzgardan korunmuş, mikroklimatik bir iklim özelliği taşımaktadır. Tasarım alanının en önemli sorunlarından birisi estetik ve fonksiyonel yapı elemanlarının bulunmamasıdır. Buna ilaveten alandaki diğer kullanıcı sorunları; bakımsız çim yüzeyler, sert zemin yetersizliği, otopark sorunu, alan içi ve fakülteler arası ulaşım yetersizliği, ışıklandırma sorunu/güvenlik sorunu, oturma dinlenme mekanlarının bulunmaması, su öğesinin kullanılmaması, diğer donatı elemanlarının yetersizliği olarak belirlenmiştir (Şekil 2).

Alanda yapısal eleman olarak saat kulesi, yürüme yolları, otopark mevcut olup, yeșil dokuda ise bakımsız çim alanlarda rastgele dikilmiş sarıçam (Pinus slyvestris), kavak (Populus alba), akçaağaç (Acer negundo), iğde (Eleagnus angustifolia), frenk üzümü (Ribes aureum), salkım söğüt (Salix babylonica), dişbudak (Fraxinus america) ağırlıklı olarak bitkiler kullanılmıștır(Şekil 2).

\section{Peyzaj tasarım projesi/kesin proje}

Alanda yapilan analiz, sorun tanımlama ve değerlendirme sonucu hazırlanan avan proje geliștirilerek peyzaj tasarım projesi/kesin proje hazırlanmıştır.

Mevcut durum analizi sonrasinda mevcut sorun ve talepler, estetik ve ekolojik kaygılar sonrası ortaya çıkan eğilimler sonrasında analizler yapılarak tasarım ilkelerine göre işlev ve leke çalışmaları oluşturulmuştur (Şekil 3). Alanın farklı alan kullanımlarına yönelik avan projeleri oluşturulmuş ve yetkililerle yapılan sunulardan sonra alana uygulanacak kesin projeye karar verilmiştir (Şekil 4).

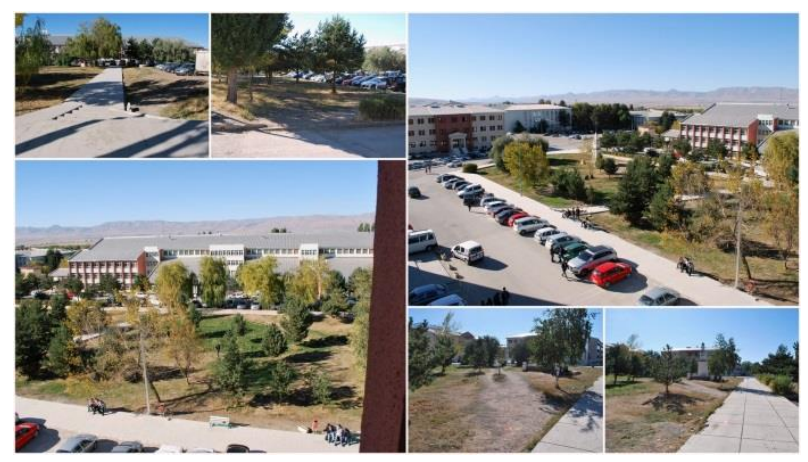

Şekil 2. Peyzaj tasarımı öncesi alanın mevcut durumu (Aksu, 2016)

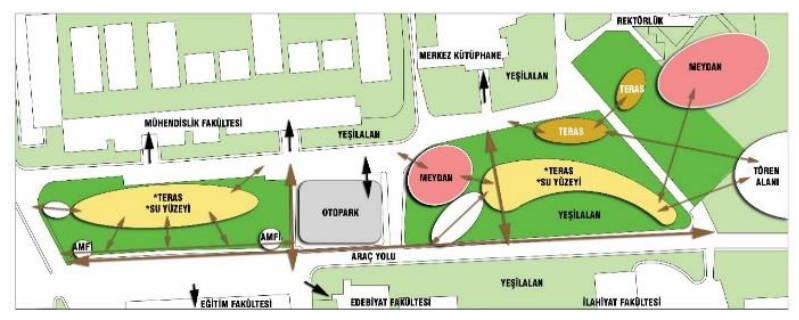

Şekil 3. Alanın leke ve fonksiyonel kullanım önerisi

Atatürk Üniversitesi Rektörlüğüne bu alanın yeni bir peyzaj tasarımı ile ele alınması konusunda bilgi verilmiş ve yetkililerden yeni bir tasarıma ihtiyaç duyulduğu konusunda onay alınmıştır. Alanın iklim yapısı özelikle sıcaklık/ güneşlenme, hakim rüzgar yönü, kar örtüsü ve yerde kalma süresi, yağış ve nem durumu, toprak yapısı, arazinin eğim durumu analiz edilmiştir. Alanın çevresindeki fakülte ve diğer eğitim dokusu ilişkisi ulaşım, otopark, eğitim zamanı (gündüz ve gece eğitim, yaz okulu), öğrenci sayısı, mevcut alan kullanımları gibi faktörler tasarımın ortaya konmasında etkili olmuştur.

\section{Yapısal tasarımlar}

Sürdürülebilir üniversite yerleşkelerinde fiziki yapılaşma önemlidir (Hajrasouliha, 2017, Matloob ve ark., 2017, WEB, 2017a). Rekreasyonel yapılan 
yapılar, park yerleri, açık yeşil alanlar, bina yoğunluğu vb. alanlar yerleşke kalitesine doğrudan etki eder (WEB, 2017b).

Eğitim dokusu içinde kalan tasarım alanında daha çok bölge ve çevre peyzajına uygun, ekonomik, ekolojik, sürdürülebilir ve yönetilebilir olabilecek yapısal tasarımlara yer verilmiştir. Alan içinde yüksek katlı, görüntüyü bozacak, alana yapısal yük getirecek tasarımlardan kaçınılmıştır. Nitekim Kılıçaslan ve ark., (2015)'ne göre, yerleşke tasarım çalışmalarında kullanıcı kitlesine hizmet veren, çevresel ve finansal yönden uygulanabilir, bütüncül ve geliştirilebilir yapıda tasarımlara yer verilmesi önerilmektedir.

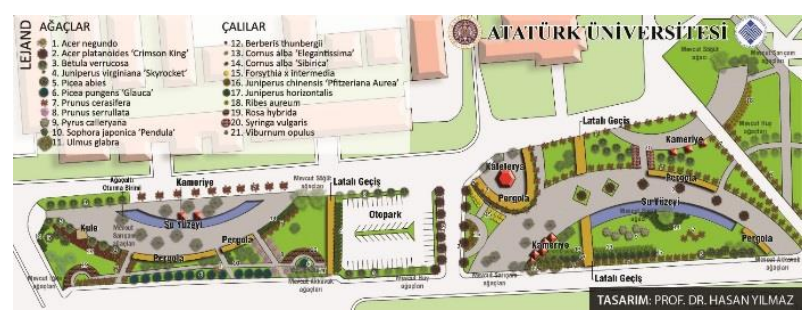

Şekil 4. Alan için hazırlanan yapısal ve bitkisel peyzaj tasarımı

Yapılan peyzaj tasarımı sonucu alanda; 1 adet ahşap kafeterya binası, 2 adet büyük teras, 2 adet süs havuzu, oturma birimleri, yürüme yolları, otopark ve donatı elemanlarına yer verilmiştir (Şekil 4).

Ahşap kafeterya alanı kullananların yanı sıra özellikle yoğun olarak kullanılan üniversite kütüphanesinin yanına tasarlanarak, öğrencilerin rekreasyonel taleplerinin karşılanması amaçlanmıştır. Aynı zamanda bu alan tüm üniversite sakinlerinin de yararlanacak bir alan olmasından dolayı etrafı geniş bir teras üzerinde ahşap daire şeklinde pergolalara yer verilmiştir (Şekil 4). Bu alanın diğer mekanlardan ayırıcı özellik göstermesi açısından teras kısmı değişik bitkiler kullanılarak, özel bir mekana dönüştürülmüştür. Bu alandaki pergolalar 2017 yılında yapılan EYOF Kış Sporları yarışlarında satış ünitelerinin olduğu bir merkeze dönüştürülmüștür.

Mekanı kullanabilecek çok sayıda öğrenci göz önüne alınarak alan içerisinde birbirinden farklı alanlarda 2 adet büyük, informal teraslara yer verilmiştir (Şekil 4). Birinci teras çok sayıda öğrencisi olan Eğitim ve Mühendislik Fakülteleri, Yabancı Diller Yüksekokulu ile Merkezi anfilere yakın olacak șekilde planlanmıștır. İkinci teras ise Fen, Edebiyat, İktisadi ve İdari Bilimler ile İlahiyat fakülteleri ile merkezi Kütüphaneye gelen öğrencilere hizmet vermesi amacıyla bu alanlara yakın olarak tasarlanmıştır. $\mathrm{Bu}$ alanı sadece yakınındaki eğitim dokusu değil, tüm üniversite sakinlerinin de kullanacağı düşüncesi ile büyük olarak tasarlanmıştır. Bu alanlarda görsel etki (Bulut ve Yılmaz, 2009), dinlendirici ve yatıștırıcı etkisinden dolayı (Rumao, 2016) su öğesine yer verilmiş, hareketli su yüzeyleri tasarlanmıştır.

Teras içinde kapalı kameriyeler ve pergola sistemleri oluşturulmuştur (Şekil 4). Yaz aylarında güneşin yakıcı etkisinden korunmak amacı ile pergola sistemlerinden özellikle fakülteleri ve mekanları birbirine bağlayan kısa yollardan yararlanılmıștır. Her iki teras içinde mevcut ağaçlar korunmuş ve bu ağaçların altlarına emprenyeli ahşap oturma birimleri kullanılmıştır. Dış mekanlarda açık ve kapalı oturma birimleri öğrencilerin en çok istediği donatı elemanlarındandır (Rumao, 2016). Sosyalleşme ile kafeterya ve oturma alanları arasında güçlü bir ilişki olduğundan (Peschardt ve ark., 2016) oturma yerleri fazla tutulmuştur. Eğimin uygun olduğu alanlarda 2 farklı noktada anfi şeklinde ahşap oturma birimleri ile bahçede sakin oturma mekanları tasarlanmıştır (Şekil 4). Teras alanlarında çoğunlukla bölgenin doğal taşı olan andezit taşı kullanılmıştır.

Eğitim dokusu binaları dikkate alınarak alan içinde çok sayıda yaya ve araç yollarına yer verilmiştir. Alan çevresindeki kaldırımlar bahçenin korunması ve yaya yolları kullanılmasını teşvik etmek ve alana görsel katkı sağlaması amacı ile küçük çitlerle bahçeden ayrılmıştır.

Alanın aydınlatılması için dekoratif bahçe direk aydınlatması ve bitkilere spot ışı verecek şekilde düşünülmüştür. Alanda çok sayıda ahşap bank, çöp kutusu, bitki kasalarına yer verilmiștir. Eğitim dokusu içinde kalan bu alanda otopark sorununu kısmen çözmek amacı ile daha önce otopark olarak kullanılan alan büyütülerek, yol üzerlerine park edilen araçların önüne geçilmesi hedeflenmiştir.

\section{Bitkisel tasarım}

Bitkisel tasarım projesinin hazırlanmasında alanın birçok eğitim kurumunun ortak avlusu konumunda olması, merkezde bir hava koridorunun varlığı, iklimsel açıdan açık alanlara göre kısmen daha elverişli iklime sahip olma özelliği, üniversite tören alanının yanında bulunması, eğitim dokusundan/bina içinden sürekli izlenme şansı bulunması, çevredeki ve ana ulaşım akslarındaki yeşil doku ile bağlantı oluşturacak bir yeşil koridor özelliği taşıması gibi tasarım kriterleri göz önünde tutulmuştur. Alanın bitkisel tasarımında alanda daha 
önceden rastgele dikilmiș sarıçam ağırlıklı mevcut bitkisel dokusu tamamen korunmuștur. Çoğu kez yeni bitkisel tasarımda mevcut bitki örtüsünün varlığı sınırlandırıcı bir faktör olmuştur.

Bitkisel tasarımda; renk, ölçü, form, doku, simgesel soğuk ikim bitkileri gibi tasarım öğeleri ile zıtlık, tekrar, denge, egemenlik, ritim ve birlik gibi tasarım ilkeleri temel alınmıştır. Alanın ekstrem iklim değerleri, rüzgar, don, sıcaklık değişimleri, yağmur gibi iklim parametreleri ile toprak yapısı, mevcut ağaç ve çalı varlığı ve öneri alan kullanımları (meydan, teras, otopark, yürüme yolları, çim yüzeyler, vb) göz önüne alınarak bitki türleri seçilmiştir. Alanın çevresindeki eğitim dokusundan alanın üstten kolayca izlenebilmesi bitkisel tasarım kararlarını etkilemiş, bu amaçla bütün mevsimlerde görsel etki oluşturabilecek /ardışık bitkisel tasarımlara gidilmiştir. Ayrıca Liu and Sullivan (2016)'a göre eğitim dokusu içinde sınıfların yeşil bir çevreyi görmesi öğrencilerin stresini ve zihinsel yorgunluğunu azaltmaktadır. Alanın kullanıcılarına güvenlik açısından baskı oluşturmayacak bitkisel tasarımlara özen gösterilmiș, özelikle çalı grupları alan çevresinde yer verilerek, orta mekanlar olabildiğince çim yüzeyleri ve üstten dallanan bitki türleri ile desteklenmiştir. Nitekim yaplan bir araştırmada sık ve yoğun bitkilendirmenin suç oranını artırdığı tespit edilmiştir (Donovan and Prestemon, 2012). Bununla beraber bitki çeşitliliğinin fazla olması ve ağaçlar çevre eğitimine katkı sağlaması yanı sıra insanın kendini daha iyi hissetmesine yardımcı olur (Fuller ve ark., 2007; Virginia ve ark. 2018).

Atatürk Üniversitesi yerleșkesinde özellikle yaz aylarında yeşil ağırlıklı bir plantasyon olduğundan bu alanda renkli bitki türleri seçimine özellikle ağırlık verilmiștir. Çiçek, yaprak, göve arke, sonbahar yaprak renkleri ve kış aylarında sürgün renkleri ile etkili olan bitki türleri seçilmiştir.

Çiçek renkleri ile etkili olan Malus hybrida, Prunus serrulata, Pyrus calleryana, Viburnum opulus, Syringa vulgaris, Forysthia intermedia'lar kullanılmış, yaz aylarında renkli yaprakları için Acer platanoides 'Crimson King', Prunus ceracifere 'Pisardii Nigra', Berberris thunbergia 'Atropurpurea', Picea pungens 'Glauca' (mavi renk), göve arke, dal ve sürgün beyaz renkleri ile sonbahar sarı yaprak renklenmesi için Betula verrucosa'lar kullanılmıștır. Ayrıca sonbahar yaprak renkleri için alanda Viburnum opulus (pembe-bordomsu renk), Spirea vanhothei (kırmızımsı renk), Ribes aureum (kırmızımsı renk),
Fraxinus americana (sarı renk), Salix babylonica (sarı renk), Pyrus calleryana (kırmızımsı renk)'lara yer verilmiştir. Özellikle kış aylarında kırmızımsı sürgünleri kar örtüsü ile zitllk oluşturan Cornus alba 'Sibirica'lar ile sarı sürgünleri ile etkili olan Cornus alba 'Elegantissima'lar tercih edilmiştir. Süs elmaları alanda en fazla yer verilen bitki türü olup, özelikle alanın çevresine renk ve formu için yoğun olarak kullanılmıştır (Şekil 4 ). Mavi ladin (Picea pungens 'Glauca') ve Avrupa ladinleri (Picea abies) dinamik yapıları, renkleri ve kış manzaraları amacı ile alan sınırları ve geniş çim yüzeylerde bitkisel tasarımda yer verilmiştir. Meydanlarda mevcut bitki örtüsüne ilaveten kırmızı yapraklı akçaağaçlar (Acer platanoides 'Crimson King') tercih edilmiştir. Alan içi kısa yol bağlantılarında tekrar ritim, birlik ve denge ilkesi göz önüne alınarak form, ölçü, doku ve renk bakımından aynı olan bitkilere yer verilmiştir. Bazı sert zeminlerin yumuşatılmasında geniş gül kolleksiyonları (Rosa hybrida) ile ahşap bitki kasaları kullanılmıştır. Yürüme yolları ve oturma birimlerinde yazın sıcaktan (Srivanit and Hakou 2013), kışın ise kar örtüsü yansımalardan meydan gelen fazla ıșıktan korumak amacı ile gölgeli ağaçlara yer verilmiștir. Nitekim yapılan bir çalıșmada kıș aylarında sarıçamların güneșten gelen ıșığı absorbe ederek, insan biyoklimatik konforuna katkı sağladığı belirlenmiştir (Yılmaz ve ark. 2008). Gürültü ve tozdan korunmak amacıyla çalılar daha çok alanın sınırlarında kullanılmıştır.

\section{Peyzaj tasarım projesinin uygulanması}

Çalışma alanı için 2014 yılında peyzaj tasarım projesi hazırlanmıştır. Projenin ihalesi Atatürk Üniversite Yapı İşleri ve Teknik Daire Başkanlığı tarafından yapılmış, proje uygulaması ise Eylül 2014 tarihinde başlatılmıştır. Kasım 2015 tarihinde ise proje uygulaması tamamlanmıştır (Şekil 5). Tasarımcı görüşleri dikkate alınarak alandaki yürüme yollarında değișik baskı beton uygulaması, alana bir çeşme yerleştirilmesi, sulama sistemlerinin oluşturulması, aydınlatma sistemleri ve uygulaması daha çok üniversitenin ilgili teknik birimi tarafından seçilmiştir. Bununla beraber uygulama aşamasında tüm yapısal ve bitkisel uygulamalara bizzat katılım sağlanmış, kontrol mühendisleri ve yüklenici firma/uygulayıcılarla proje aplikasyonu beraber gerçekleştirilmiştir.

\section{Uygulama sonrası alanın mevcut durumu ve alan yönetimi}

Peyzaj mekanları yaşayan bir süreç olup, mekan organizasyonlarından istenilen başarıyı elde etmek 
için belirli bir sürece ihtiyaç vardır. Günümüzde büyük boylu fidanlarla her ne kadar bitkisel uygulamalar yapılsa da alanın kendi ekosistemini kurması zaman almaktadır. Mekan kullanılıp, tanınırlığı arttıkça, bitkiler gelişip, tüm estetik, fonksiyonel özeliklerini ortaya çıkarmaya başladıkça peyzaj tasarımı etkisini göstermeye başlamaktadır. Nitekim bu alan ile ilgili yapılan bir araştırmada (Aksu, 2016), peyzaj tasarım uygulaması sonrası yapılan anketlerle kullanıcı memnuniyetinin arttığı, katılımclların \%75,6'sının alanda yapılan tasarımın gerekli olduğuna inandıkları ve tasarım yapılan bu alanın üniversiteye prestij kazandırdığı belirlenmiștir.

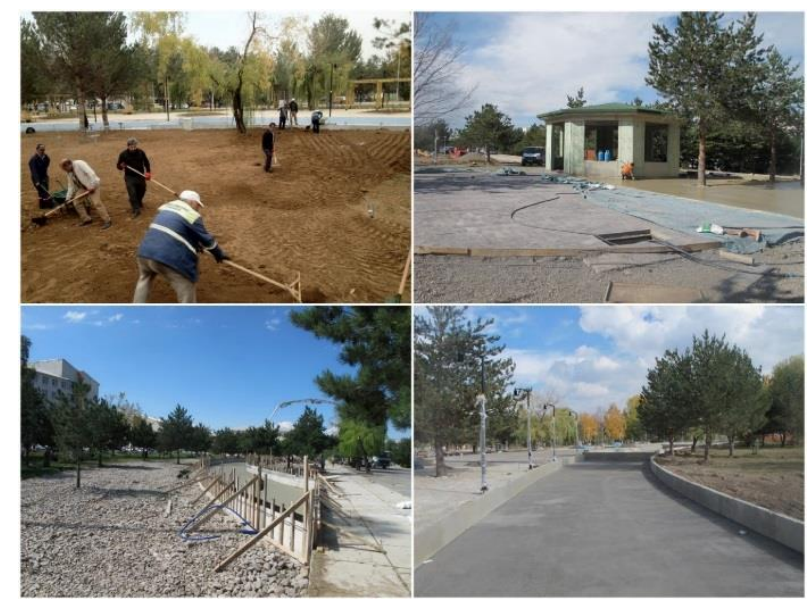

Şekil 5. Peyzaj tasarımın uygulaması örnekleri

Bugün gelinen noktada alanın su yüzeyleri, teras, oturma birimleri, çim yüzeyleri ile üniversite sakinleri tarafından beğeni ile gündüz ve gece yoğun olarak kullanılmaktadır (Şekil 6). Bitkilerin değişik dönemlerde ortaya çıkardığı renk gösterileri dikkate değerdir. $\mathrm{Bu}$ etki şüphesiz bitkiler büyüdükçe artarak devam edecektir. Alan içinde yapılan kafeterya ve kameriyeler de eğitim sezonunda öğrenciler ve üniversite mensupları tarafından yoğun talep görmektedir. Nitekim, yeşil örtünün ağırlık kazandığı üniversite yerleşkeleri mekanı kullanan öğrencilere bir çok olumlu katkı sağlayacağı (Hipp ve ark., 2016.) beklenmektedir. Yerleşkenin en değerli açık-yeşil sahip olan bu alan uygulanan peyzaj tasarım sayesinde olası fiziki yapılaşmadan korunmuştur (Şekil 7).

Alan üniversitenin yeşil saha ekipleri tarafından bakım (budama, çim biçme, temizlik, ekstra sulama vb.), onarım ve kontrolü sağlanmaktadır. Alan içindeki bitki kasaları ve çiçek parterlerine her yıl düzenli olarak çiçek dikimi ve bakımı yapılmaktadır.

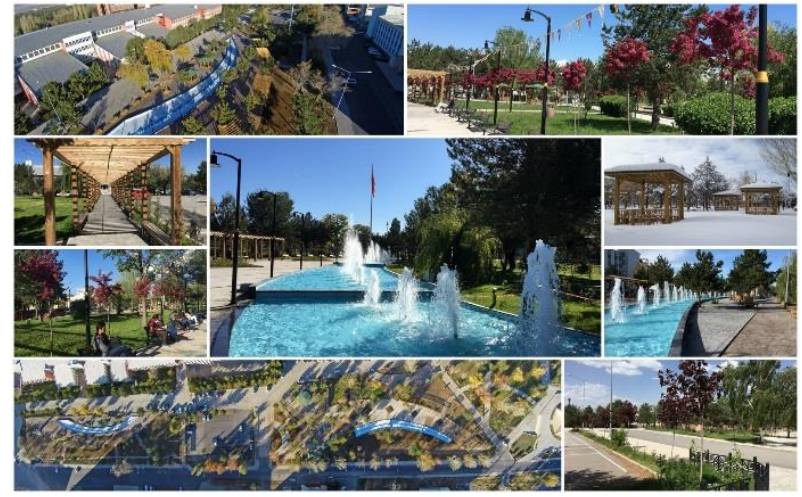

Şekil 6. Peyzaj tasarımı uygulaması sonrası alanın genel görünümleri

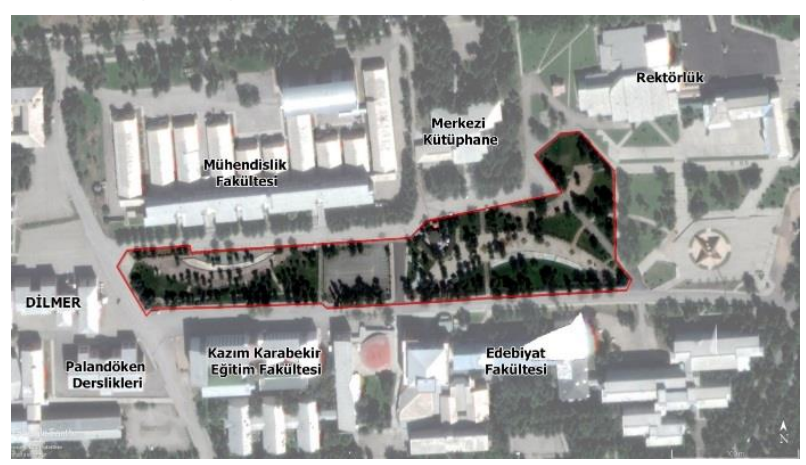

Şekil 7. Alanın tasarım sonrası uydu görüntüsü

\section{Sonuç}

Bu çalışmada ülkemizin en köklü üniversitelerinden birisi olan büyüklüğü, özgün planlaması, açık yeşil alanlarının varlığı, kentle ilişkisi, öğrencilere ve akademik personele sunduğu sosyo- ekonomik fırsatları ile en önemli üniversite yerleşkelerinden birisi olarak kabul edilen Atatürk Üniversitesi merkez yerleşkesinde yürütülmüştür.

Peyzaj tasarım süreci kapsamında ele alınan bu çalışma ile üniversite merkez yerleşkesi içinde 2014 yılında uygulamaya başlanılan proje, 2015 yılında tamamlanarak hizmete girmiştir (Şekil 7). Çalışmanın tüm aşamaları rektörlüğe bağlı ilgili birimlerin kontrolünde yürütülmüștür. Alana yeni bir fonksiyon yüklenerek öğrencilerin ve akademik/idari personelin serbest zamanlarını geçirebilecekleri, çevre ile uyumlu, sürdürülebilir, konforlu, güvenli ve estetik, ekolojik bir tasarım ürünü ortaya çıkmıştır. Yapısal ve bitkisel tasarımlarda ekonomik, ekolojik ve fonksiyonel, iklim şartlarına dayanıklı, alana fazla yapısal yük getirmeyen, üniversite kimliğine ve prestijine katkı sağlayan, çevre dokusu ile uyumlu, eğitim dokusu ile doğrudan ilişkili, gece ve gündüz kullanılabilen mekan tasarımlarının oluşturulmasına dikkat edilmiştir. $\mathrm{Bu}$ uygulama projesinin en önemli 
çıktılarından birisi de merkez yerleşkenin en önemli açık yeșil alanı olan merkez avlu fiziki yapılaşma baskısından kurtarılmıştır.

Ata Botanik Bahçesinde denemesi yapılan ve bölgeye dayanıklı bazı bitkiler yerleşkede ilk kez bu alanda kullanılmış ve başarılı sonuçlar alınmıştır. $\mathrm{Bu}$ bitkilerden bazıları; ahlat (Pyrus elaeagnifolia), sophora (Sophora japonica 'Pendula'), süs armudu (Pyrus calleryana), süs kızılcı̆̆ (Cornus alba 'Elegantisssima'), süs kirazı (Prunus serrulata 'Kanzan'), sütun ardıç (Juniperus virginnianana 'Sky Rocket')'lardır. Bugün üniversite sakinlerinin yoğun olarak ve beğeni ile kullandıkları mekanın, zamanla bitkilerin daha da büyümesi ile ekolojik, fonksiyonel ve estetik açıdan öneminin daha da artması beklenmektedir.

Üniversite eğitimi sadece sınıflarda değil, bütün yerleşkede kazanılır. Özelikle kışları sert ve uzun geçen yerleşke alanında diş mekan fiziki plan ve tasarımları öğrencilere, akademik ve idari personele ve yerleşkeye gelen ziyaretçilere daha çok rekreatif fırsat sağlamaya yönelik olmalıdır.

$\mathrm{Bu}$ çalışmada peyzaj tasarım süreci eşliğinde üniversite karar vericileri ve ilgili birimleri gözetiminde yürütülen bu tasarım ve uygulama çalışmasından başarılı sonuçlar elde edilmiştir. Üniversitenin yerleşke dokusundaki tüm açı yeşil alan planlama ve tasarımlarında benzer bir süreç izlenmelidir.

Yerleșke alanı içinde tüm fiziki yapılașma uzman ve kullanıcı talepleri doğrultusunda hazırlanan bir fiziki gelișim planı üzerinde yürütülmelidir (Yılmaz ve Irmak, 2012, WEB, 2017b). Özelikle fakültelerin yapısal ve bitkisel tasarımlarında konu uzmanları söz sahibi olmalı, yerleşkenin bütüncül peyzaj planlamasını bozacak/sekteye uğratacak, çevreyle uyumsuz, ekolojik, ekonomik, sürdürülebilir, estetik ve fonksiyonel olmayan sıradan tasarım ve uygulamaların önüne geçilmelidir.

\section{Kaynaklar}

Aksu, A., 2016. Atatürk Üniversitesi Merkezi Açık-Yeşil alandaki Fiziki Değişim Memnuniyetinin Belirlenmesi. Atatürk Üniv. Fen Bilimleri Enst. (Basılmamış) Yüksek Lisans Tezi, Erzurum. 129s.

Bulut, Z., Yilmaz, H., 2009. Determination of waterscape beauties through visual quality assessment method .Environmental Monitoring and Assessment 154(1-4): 459-468.
Dober, R.P., 2000. Campus Landscape:Functions, form, Features. John Wiley and Sons, Inc, New York.

Donovan, G.H., Prestemon, J.P., 2012. The effects of trees on crime in Portland, Oregon. Environment and Behavior. 44: 13-30.

Fuller, R.A., Invine, K.N., Devine-Wright, P., Warren, P.H., Gaston, K.J., 2007. Psychological benefits of green spaces increase with biodivinity. Biology Letters, 3(4): 390-384.

Hajrasouliha, A., 2017. Campus score:Measuring universty campus qualities. Landscape and Urban Planning, 158: $166-176$.

Hipp, J.A., Gulvadi, G.B., Alves, S., Sequeri,a S., 2016. The relationship between perceived greness and perceived restorativeness of universty campus and student_reported quality of life. Environment and Behavior, 48(10): 1292-1308.

Hodson, C.B, Sander, H.A., 2017. Green urban landscapes and school-level academiz performance. Landscape and Urban Planning, 160: 16-27.

Kılıçaslan, Ç., Deniz, B., Göktuğ, T.H., Kara, B., 2015. Adnan Menderes Üniv. Güney Yerleșkesi Örneğinde Töreb ve Toplanma Alanı Tasarım Süreci. ISBN 978-6059932-89-9, Ankara, 47s.

Liu, D., Sullivan, W.C., 2016. Impact of views to school landscapes on recovery from stress and menral fatigue. Landscape and Urban Planning, 148: 149158.

Matloob, F.A., Sulaiman, A.B., Turki, H.A., Shamsuddin, S., Mardyya, W.N., 2014. Sustaining Campuses through Physical Character-The Role of Landscape. Procedia-Social and Behavioral Sciences, 140: 282290.

Peschardt, K.K., Stigsdotter, U.K., Schipperrijn, J., 2016. Identififying features of pocket parks that may be related to heallty promoting use. Landscape Research, 41(1): 79-94.

Önder, S., Polat, A.T., 2001. Konya Büyükşehir Belediyesi Park ve Bahçeler Müdürlüğü açık alan tasarımı üzerine bir araștırma. SÜ. Ziraat Fak. Dergisi, 15(28): 153-167.

Özkan, M.B., Küçükerbaş, E.V., Kaplan, A., Aslan, N., 1993. Ülkemizde Peyzaj Düzenleme Çalışmalarında Tasarım Süreci Açısından Gözlenen Sonuçların Bademler Mahmut Türkmenoğlu Parkı Örneğinde Çözümü Üzerine araştırmalar. EÜ. Ziraat Fak. İzmir. $29 \mathrm{~s}$.

Öztürk, M., Gökyer, E., Çorbacı, Ö.L., 2016. Evaluation of student perception on landscape planning and design of university campuses around the case of 
Ağdacı campus, Bartın University, Turkey. İnönü University Journal of Art and Design 6(13): 49-55.

Srivanit, M., Hokau, K., 2013. Evaluating the cooling effects of greening for improving the outdoor thermal environment at an institutional campus in the summer. Building and Environment. 66: 158-172.

Rumao, G.S., 2016. Assessing users' perceptions of campus landscapes learning from the university of Texas at Arlington. Degree of Master of Landscape Arcitecture. https//uta-ir.tdl.org.

Turgut, H., Yeşil P., Yılmaz S., 2009. Determining the recreational demands and tendencies of students at Atatürk University through questionnaires, Scientific Research and Essay.4(3): 152-158.

WEB, 2017a. Campus Plan Princeton University/ Landscape master plan. https//campusplan princeton.edu (Erişim tarihi:29.03.2018)
WEB, 2017b. Campus Master Planning Process. senata.Illinois.edu/master.pdf. (Erişim tarihi:29.03.2018)

Virhinia, H., Kendal, D., Hahs, A.K., Threlfoll, C.G., 2018. Green space context and vegetation complexity shape people's preferences for urban public parks and residental gardens. Landscape Research, 43(1): 150-162.

Yılmaz, H., Yılmaz, S., 2000. Peyzaj Mimarlı̆̆ında Tasarım Süreci ve Proje Örnekleri.Bakanlar Matbaası, 106s.

Yılmaz, H., Demircioğlu, N., Yılmaz, S., 2008. Effects of snow reflected light levels on human visual comfort. Environmental monitoring and Assesment.144:367-375.

Yılmaz, H., Irmak, M.A., 2012. Yerleşke Planlamasında Bitkisel Tasarım İlkeleri: Atatürk Üniversitesi Yerleşkesi Örneği. Atatürk Üniv. Yayın No:1011,192s. 